\title{
Analisis Pemahaman Konsep Magnet Mahasiswa Calon Guru Fisika
}

\author{
Abdul Basit Pateda, Yusuf Kendek, dan Sahrul Saehana \\ pateda118@gmail.com \\ Program Studi Pendidikan Fisika, Jurusan Pendidikan MIPA, Universitas Tadulako, \\ Jl. Soekarno Hatta KM. 9 Kampus Bumi Tadulako Tondo Palu - Sulawesi Tengah
}

\begin{abstract}
Penelitian ini bertujuan untuk mengkaji, menganalisis dan mendeskripsikan pemahaman konsep magnet mahasiswa calon guru fisika. Responden penelitian ini terdiri dari 6 orang mahasiswa calon guru fisika. Data diperoleh melalui tes pilihan ganda beralasan yang berjumlah 18 butir soal. Soal tersebut disusun berdasarkan kategori-kategori pemahaman konsep. Dalam hal ini dibatasi pada kategori menafsirkan, mencontohkan, mengklasifikasikan, menyimpulkan, dan menjelaskan. Data penelitian dianalisis melalui pendekatan deskriptif-kualitatif dengan merujuk pada alasan jawaban soal pemahaman konsep magnet yang diberikan oleh para responden dan juga berdasarkan hasil wawancara antara peneliti dengan responden. Hasil penelitian menunjukkan bahwa Pemahaman konsep mahasiswa calon guru fisika tentang gaya Lorentz, medan magnet, dan penentuan kutub magnet masih tergolong rendah. Sebaiknya, pemahaman konsep tidak diabaikan dalam kegiatan belajar dan pembelajaran.
\end{abstract}

Kata Kunci: pemahaman konsep, magnet

\section{PENDAHULUAN}

Hakikat tujuan pembelajaran fisika adalah untuk mengantarkan pemahaman siswa menguasai konsep-konsep dan keterkaitannya untuk dapat memecahkan masalah terkait dalam kehidupan sehari-hari. Menguasai memiliki arti bahwa pembelajaran fisika harus menjadikan siswa tidak sekedar tahu (knowing) dan hafal (memorizing) tentang konsep-konsep, melainkan harus menjadikan siswa mengerti dan memahami (to understand) konsep-konsep tersebut dan menghubungkan keterkaitan suatu konsep dengan konsep lain [1].

Pemahaman mahasiswa sebagai calon guru dalam menguasai konsep-konsep fisika akan mempengaruhi tercapainya tujuan pendidikan dalam proses belajar dan pembelajaran tidak dapat terwujud dan terhambat. Oleh karena itu sebagai calon guru harus memahami konsep-konsep yang sudah ditentukan dan lebih bijaksana dalam menentukan model atau strategi pembelajaran [2].

Karakteristik penyiapan calon guru fisika harus memenuhi standar sebagai berikut: (1) mempelajari fisika dengan metode yang sama ketika ia mengajar, (2) mendapatkan pengetahuan tentang bagaimana siswa belajar dan bagaimana mereka mempelajari fisika, (3) terlibat dalam lingkungan pembelajaran yang sama dengan lingkungan yang hendak ia ciptakan ketika mengajar, (4) tuntas dalam penguasaan teknologi, metode, keterampilan yang akan mereka gunakan di kelas, (5) mempelajari cara melibatkan siswanya dalam praktek kerja ilmiah, (6) memahami konsepkonsep serta penerapannya secara fleksibel, (7) memahami proses berpikir fisika, bernalar secara kualitatif maupun kuantitatif tentang proses dan hukum fisika[3].

Banyak mahasiswa tidak memahami konsep gaya magnet dan medan magnet, serta teridentifikasi adanya kesalahan konsep dalam memahami sumber medan magnet [4]. Selain itu juga banyak mahasiswa mengalami kesalahan konsep tentang representasi garis medan, hal ini karena pengetahuan mahasiswa tidak sistematis dan kacau, terutama pada konsep arah medan magnet dan penerapannya [5].

Berdasarkan hasil penelitian-penelitian di atas, peneliti terdorong untuk melakukan penelitian tentang pemahaman konsep magnet mahasiswa calon guru fisika yang berada di salah satu Universitas Negeri di Kota Palu. Karena sebagai calon seorang guru fisika, kiranya harus memahami konsep magnet yang merupakan bagian dari pembelajaran fisika.

\section{METOde PENELITIAN}

Penelitian ini merupakan penelitian kualitatif yang datanya berupa fakta-fakta yang ada, sehingga dalam penelitian ini digunakan pendekatan deskriptif kualitatif. Responden dalam penelitian ini berjumlah 6 
orang yang dipilih berdasarkan kategori tinggi, sedang, dan rendah. Responden tersebut diberikan tes pilhan ganda beralasan dan mengikuti wawancara mengenai penelusuran terhadap pemahaman konsep magnet yang dimiliki mahasiswa. Enam responden tersebut diperoleh dari tes awal dan kemudian menghitung nilai rata-rata mahasiswa dan standar deviasi dengan menggunakan persamaan 1 dan persamaan 2 .

$$
\begin{aligned}
& \bar{X}=\frac{\sum X i}{\hbar} \\
& S D=\sqrt{\frac{\sum\left(X_{i}-\overline{X^{2}}\right)^{2}}{n}}
\end{aligned}
$$

Dengan :

$\bar{x}=$ rata-rata nilai yang diperoleh siswa

$\mathrm{n}$ = banyaknya sampel

$\mathrm{SD}=$ standar deviasi

kategori tinggi, sedang dan rendah di peroleh dari [6] :

- Kategori tinggi, diperoleh dengan rumus:

$$
\text { Nilai }>\bar{x}+\text { SD }
$$

- Kategori sedang, diperoleh dengan rumus:

$$
\bar{x}-\mathrm{SD} \leq \text { Nilai } \leq \bar{x}+\mathrm{SD}
$$

- Kategori rendah, diperoleh dengan rumus:

$$
\text { Nilai }<\bar{x}-\mathrm{SD}
$$

Alasan yang diberikan oleh mahasiswa dianalisis dan disesuaikan dengan pilihan jawaban yang dipilih. Kesesuaian antara pilihan jawaban yang benar dan alasan akan menunjukkan penguasaan konsep yang dimiliki mahasiswa calon guru fisika.

\section{HASIL DAN PEMBAHASAN}

Soal tes yang diberikan kepada responden merupakan soal pilihan ganda beralasan. Soal tersebut dibuat berdasarkan kategori-kategori dari pemahaman konsep. Adapun distribusi soal berdasarkan kategori pemahaman konsep disajikan dalam Tabel 1.

Tabel 1. Distribusi soal berdasarkan kategori pemahaman konsep

\begin{tabular}{|c|c|c|}
\hline No & $\begin{array}{c}\text { Kategori } \\
\text { Pemahaman Konsep }\end{array}$ & Nomor Soal \\
\hline 1 & Menafsirkan & 1,2 , dan 3 \\
\hline 2 & Mencontohkan & 4 dan 5 \\
\hline 3 & Mengklasifikasikan & $6,7,8$, dan 9 \\
\hline 4 & Menyimpulkan & 10,11 , dan 12 \\
\hline 5 & Membandingkan & 13,14, dan 15 \\
\hline 6 & menjelaskan & 16,17 , dan 18 \\
\hline
\end{tabular}

Adapun deskripsi jawaban dari responden disajikan pada Tabel 2

Tabel 2. Deskripsi Jawaban Responden

\begin{tabular}{|c|c|c|c|c|c|c|}
\hline $\begin{array}{c}\text { No. } \\
\text { Soal }\end{array}$ & $\begin{array}{c}\text { Benar } \\
\text { Disertai } \\
\text { Alasan }\end{array}$ & $\begin{array}{c}\text { Benar } \\
\text { Tanpa } \\
\text { Alasan }\end{array}$ & $\begin{array}{c}\text { Salah } \\
\text { Disertai } \\
\text { Alasan }\end{array}$ & $\begin{array}{c}\text { Salah } \\
\text { Tanpa } \\
\text { Alasan }\end{array}$ & $\begin{array}{c}\text { Tidak } \\
\text { Dijawab }\end{array}$ & Total \\
\hline $\mathbf{1}$ & 1 & 1 & 3 & 1 & 0 & 6 \\
\hline $\mathbf{2}$ & 0 & 1 & 3 & 2 & 0 & 6 \\
\hline $\mathbf{3}$ & 0 & 0 & 3 & 3 & 0 & 6 \\
\hline $\mathbf{4}$ & 3 & 1 & 0 & 1 & 1 & 6 \\
\hline $\mathbf{5}$ & 0 & 2 & 1 & 3 & 0 & 6 \\
\hline $\mathbf{6}$ & 2 & 0 & 3 & 1 & 0 & 6 \\
\hline $\mathbf{7}$ & 1 & 1 & 3 & 1 & 0 & 6 \\
\hline $\mathbf{8}$ & 1 & 1 & 2 & 2 & 0 & 6 \\
\hline $\mathbf{9}$ & 1 & 0 & 2 & 3 & 0 & 6 \\
\hline $\mathbf{1 0}$ & 1 & 0 & 3 & 2 & 0 & 6 \\
\hline $\mathbf{1 1}$ & 5 & 0 & 1 & 0 & 0 & 6 \\
\hline $\mathbf{1 2}$ & 1 & 2 & 2 & 0 & 1 & 6 \\
\hline $\mathbf{1 3}$ & 1 & 0 & 2 & 2 & 1 & 6 \\
\hline $\mathbf{1 4}$ & 1 & 2 & 2 & 1 & 0 & 6 \\
\hline $\mathbf{1 5}$ & 2 & 0 & 0 & 3 & 1 & 6 \\
\hline $\mathbf{1 6}$ & 0 & 0 & 2 & 3 & 1 & 6 \\
\hline $\mathbf{1 7}$ & 1 & 1 & 4 & 0 & 0 & 6 \\
\hline $\mathbf{1 8}$ & 0 & 0 & 2 & 2 & 2 & 6 \\
\hline & & & & & & \\
\hline
\end{tabular}

Berdasarkan alasan dari pemilahan jawaban dan hasil wawancara yang dilakukan kepada para responden, terlihat bahwa pemahaman konsep magnet para responden masih tergolong rendah. Pertama untuk soal nomor 1, mencakup tentang arah gaya magnetik yang bekerja pada kawat yang digambarkan pada garis koodinat $X, Y$ dan $Z$ dengan arus menuju ke sumbu $X$ posituf seperti pada Gambar 1. Responden R01 menjawab soal ini dengan menggunakan aturan tangan kanan. Ketika soalnya diubah dengan mengganti arah magnetnya, responden masih kebingungan dalam menjawab soal itu. Untuk responden R03 juga menjawab soal ini menggunakan kaidah tangan kanan, hanya saja pada penggunaanya masih salah. Responden R03, masih salah dalam mengunakan kaidah tangan kanan dalam menyelesaikan soal. Sedangkan untuk responden R06 dalam menyelesaikan soal 
ini,juga masih salah dalam menggunakan kaidah tangan kanan.

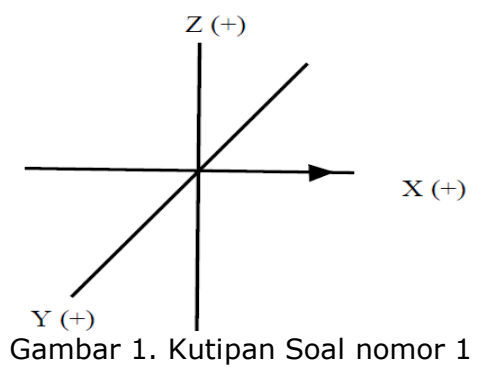

Pada soal nomor 2, mencakup tentang arah pembelokkan elektron ketika meniunggalkan kawat yang berada dalam medan magnet seperti pada Gambar 2 . Responden R02 menjawab soal ini hanya berpatokan pada lintasan arus. Dimana menurut responden tersebut bahwa kalau arus memiliki lintasan yang lurus, maka elektronnya juga lurus dan medan magnet tidak mempengaruhi elktron tersebut. Sementara responden R03, berpendapat bahwa lintasann elektronnya melingkar sehingga arahnya ke bawah. Seperti Responden R02, Responden R04, juga menjawab soal ini berpatokan pada lintasan arus, apabila arusnya lurus maka listasan elktronnya juga lurus.

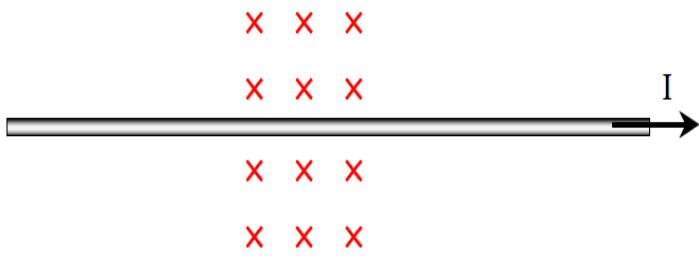

Gambar 2. Kutipan Soal nomor 2

Pada soal nomor 3, mencakup tentang penentuan arah gaya Lorentz pada kawat yang dialiri arus dan berada diantara kutub utara dan selatan magnet seperti pada Gambar 2 . Responden R-01 menggunakan kaidah tangan kanan untuk menyelesaikan soal ini, hanya masih terbalik dalam menetukan arah meda. sehingga salah dalam menentukan arah gayanya. Sama seperti responden R01, responden R05 juga menjawab bahwa arah gaya juga keluar bidang kertas. Responden R05 juga berpendapat bahwa arah arus tidak mempengaruhi arah gaya. Sedmentara R06 terbalik dalam menentukan arah medan dan arah gaya. Menurut R06 arah medan magnet masuk bidang kertas sehingga arah gayanya dari utara ke selatan. Berdasarkan soal ini, penafsiran para responden terhadap soal masih rendah. Para responden masih keliru menentukan arah gaya pada kawat yang berada diantara dua kutub magnet.

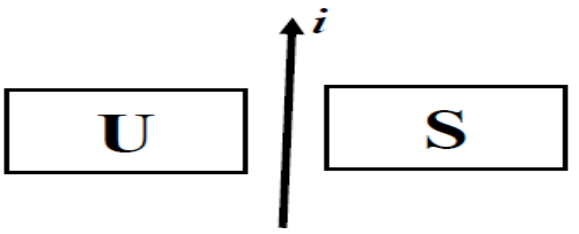

Gambar 3. Kutipan soal nomor 3

Untuk soal nomor 4, mencakup tentang contoh pemanfaatan gaya magnetik. Para responden menjawab hanya berdasarkan alat mana yang menggunakan magnet tanpa mengetahui prinsip gaya Lorentz yang berkerja pada alat yang mereka pilih. Sedangkan pada soal nomor 5, sebagian besar responden hanya menjawab berdasarkan nama dari alat misalnya kereta api magnetic levitation.

Untuk soal nomor 6, mencakup tentang mengkalisifikasikan faktor-faktor yang mempengaruhi gaya Lorentz. Sebagian besar responden memilih opsi $B$, mereka berpendapat bawha salah satu faktor yang mempengaruhi gaya Lorentz adalah arah arus searah dengan medan magnet. Disini terlihat bahwa rendahnya pemahaman mereka tentang gaya Lorentz. Pada bagian tiga sudah jelas bahwa, arah medan magnet tegak lurus kawat penghantar, dengan demikian arus juga tegak lurus dengan kawat penghantar.

Untuk soal nomor 7, mencakup tentang arah gaya yang benar berdasarkan beberapa buah gambar seperti pada Gambar 4. Responden R01 hanya memilih gambar 1dan 2. Menurut responden R01, apabila arusnya masuk maka gayanya ke bawah dan apabila arusnya keluar maka arah gayanya akan ke atas. Responden R 01 tidak memilih gambar 4, karena penunjukan arah arusnya salah. Responden R01 juga tidak memilih gambar 3, karena menurutnya antara $\mathrm{F}$ dan I tidak tegak lurus. Sementara itu, Responden R03, memilih gambar 1 dan 4 . Alasannya memilih gambar 1 sudah sesuai dengan prinsip gaya Lorentz.sedangkan untuk gammbar 4, alasannya yaitu ketika arus mengalir dari selatan ke utara maka arah gayanya akan ke atas. Pada soal ini, responden R04 mengaku masi belum paham tentang konsep gaya lorentz. Sehingga dia hanya memilih berdasarkan arah arus yang keluar. 


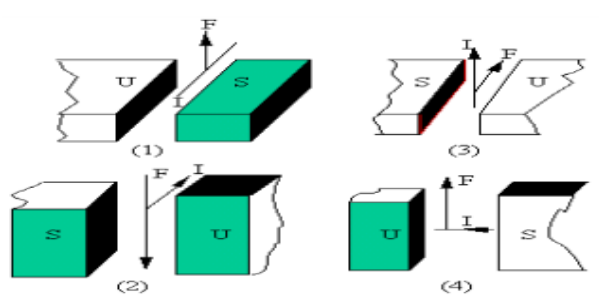

Gambar 4. Kutipan Soal nomor 7

Untuk soal nomor 8, yaitu tentang cara memperbesar induksi magnetik pada solenoida. Untuk responden R02, menjawab yaitu dengan cara memperbanyak jumlah lilitan dan memperpendek panjang solenoida. Tetapi ketika ditanyakan ada tidak persamaan yang digunakan untuk menyelesaikan persamaan ini, responden tersebut mengaku hanya menggunakan logika dan ia juga mengaku tidak mengetahui persamaan untuk mencari induksi magnetik pada solenoida. Sementara itu, responden R03, memilih memperbayak jumlah lilitan, memperbesar luas kumparan dan memperpendek panjang solenoida. Sama seperti responden R02, responden $\mathrm{R} 03$ juga tidak mengetahui persamaan medan magnet pada solenoida sehingga dalam mengerjakan soal ini tidak menggunakan persamaan itu. Begitu juga dengan responden R04, tidak memahami tentang medan magnet pada solenoida sehingga dia bisa memilih memperkecil kuat arus dalam solenoida. Untuk responden R05, ia mengaku tidak mengetahui yang bagaimana itu solenoida.

Untuk soal nomor 9, mencakup tentang klasifikasi arah medan magnetik dan arah arus di sekitar kawat penghantar seperti pada Gambar 5. Responden R01 mengaku masih bingung mengkalsifikasikan arah gaya dan arus yang benar berdasarkan gambar. Sehingga untuk menjawab soal ini hanya asal pilih sja. Responden R02, menjawab soal ini hanya berdasarkan arah medan yang ke kanan sehingga menurutnya arah medan magnet dan arah arus pada gambar 4 itu salah.
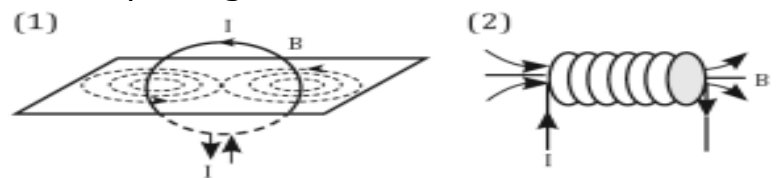

(3)

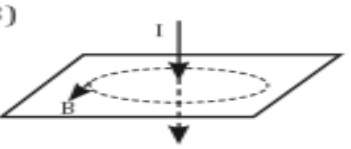

(4)

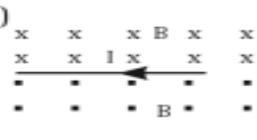

Gambar 5. Kutipan Soal nomor 9

Untuk soal nomor 10, mencakup tentang menetukan kutub magnet pada sebuah magnet batang yang dipotong-potong seperti pada Gambar 6. Pada soal ini, tidak ada responden yang menjawab benar. Berdasarkan alasan dan hasil jawaban, para responden melihat bahwa apabila sebuah magnet dipotong jika kutub utara sebelah kiri dan kutub selatan sebelah kanan, maka potongan-potongan yang sebelah kiri adalah kutub utara dan potongan potong disebelah kanan adalah kutub selatan. Berdasarka hasil tersebut, para responden menunjukan kutub magnet hanya dari bidangnya bukan tadi sisinya.

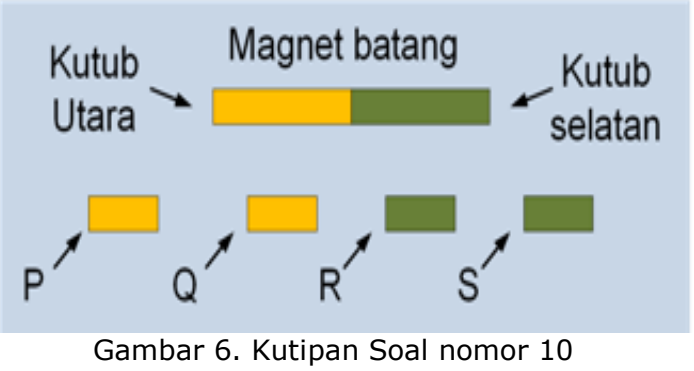

Untuk soal nomor 11, para responden tidak mengalami kesulitan menjawab soal ini. berdasarkan soal apabila ada empat buah kutub magnet $\mathrm{P}, \mathrm{Q}, \mathrm{R}$, dan $\mathrm{S}$. Hasil percobaan menunjukkan bahwa kutub $\mathrm{P}$ menarik $\mathrm{Q}$, kutub $\mathrm{P}$ menolak $\mathrm{R}$ dan kutub $\mathrm{R}$ menolak $\mathrm{S}$. Bila $\mathrm{S}$ adalah kutub utara. Para responden menyimpulkan maka $R$ kutub utara, $P$ kutub selatan, dan Q kutub selatan.

Untuk soal nomor 12, mencakup tentang penentuan lintasan partikel yang bermuatan pada daerah bermedan dengan arah tegak lurus arah gaya. Responden R02, mejawab lintasannya lurus. Alasannya yaitu apabila dia tegak lurus, maka lintasannya juga akan ikut lurus. Sama seperti R02, Responden R05 juga menjawab lintasannya lurus. Alasannya yaitu kalau arahnya tegak lurus dengan arah gaya, maka dia juga akan ikutan lurus dan tidak melengkung, dan opsi yang lain itu semuanya melengkung. Sementara itu, responden R06 menjawab lintasannya berbentuk parabolik. Alasannya yaitu apabila partikelnya semakin benrgerat, maka gayanya semakin naik.

Untuk soal nomor 13, mencakup tentang perbandingan induksi magnetik dua buah titik dari kawat berarus. Responden R03, mengaku tidak mengetahui parsamaan induksi magnetik. Sehingga untuk menyelesaikan soal ini hanya membandingkan jaraknya dari kawat saja. 
Sama seperti responden R03, responden R04 dan responden, juga tidak mengetahui persamaan induksi magnetik yang diakibatkan oleh kawat berarus. Sehingga untuk menyelesaikan soal ini hanya membandingkan jaraknya saja.

Untuk soal nomor 14, menghitung gaya Lorentz partikel apabila muatan dan kecepatan partikel tersebut diperbesar. Responden R02 mengaku tidak mengetahui persamaan yang digunakan. Responden tersebut hanya mengalikan perbesar muatan dengan perbesaran kecepatan. Begitu juga dengan responden R03 dan responden R05 tidak mengetahui persamaan yang digunakan. Sehingga untuk menyelesaikan soal ini kedua responden tesebut hanya membagi jumlah muatan dengan kecepatan. Responden R04, juga mngaku tidak memahami gaya Lorentz, dia tidak mengetahui persamaan gaya Lorentz.

Untuk soal nomor 15, mencakup tentang menentukan besar medan magnet yang arus dan jaraknya diperbesar. Sama seperti pada soal nomor 13 dan nomor 14 , sebagian besar para responden tidak mengetahui persamaan yang akan digunakan untuk menyelesaikan soal ini. Para responden haya mengalikan besarnya arus dan jaraknya.

Untuk soal nomor 16, mencakup tentang cara membedakan lintasan elektron yang sedang bergerak dalam suatu ruang dibelokkan oleh medan listrik dan medan magnet. Pada soal ini, sebagian responden hanya asal menjawab tanpa mengetahui alasannya.

Untuk soal nomor 17, mencakup tentang sebaran beberapa buah paku yang dilekatkan pada sebuah magnet. Responden R02, menjawab junlah paku semakin ke tengah semakin banyak. Alasannya karena besar medan magnetnya semakin ke tengah semakin besar. Responden R03 juga menjawab jumlah paku makin ke tengah makin banyak. Alasannya yaitu medan yang berada di kutub selatan dan kutub utara besarnya setengah dari medan magnet yang berada di tengah.sehingga medan magnet yang berada ditengah semakin banyak. Semetara itu responden R05 menyatakan bahwa jumlah paku menyebar sama rata. Responden R05 mnyetakan bahwa muatan yang berada pada magnet itu besarnya sama sehingga dia menyebar sama rata.
Untuk soal nomor 18, mencakup tentang penjelasan arah gaya apabila elektron yang memiliki kecepatan masuk secara tegak lurus pada medan magnet. Responden R02, menjelaskan bahwa arah gayanya sejajar dengan medan magnet dan tegak lurus dengan arah kecepatannya. Responden tersebut menjawab berdasarkan kaidah tangan kanan, jari tengah sebagai arah gaya dan jari telunjuk sebagai arah medan. Jadi antara gaya magnet dan medan magnet saling sejajar. Sementara responden R06, mejawab arah gayanya tegak lurus dengan $B$ dan sejajar dengan v. Pada saat ditanyakan mengenai alasannya, responden tersebut tidak dapat memberikan alasan dari jawabannya.

\section{Kesimpulan}

Berdasarkan hasil analisis tes pemahaman konsep magnet dan wawancara yang diberikan kepada mahasiswa calon guru fisika, maka dapat disimpulkan bahwa pemahaman konsep magnet mahasiswa calon guru fisika masih tergolong rendah. Mahasiswa masih memiliki kesalahan-kesalahan konsep magnet, diantaranya yaitu:

1. Pada penentuan arah gaya magnet, medan magnet, dan arus listrik dengan menggunakan kaidah tangan kanan.

2. Penentuan sebaran medan magnet pada magnet batang.

3. Penentuan kutub Magnet pada magnet batang yang telah dipotong kecil-kecil.

\section{DAFTAR PUSTAKA}

[1]Lubis, I. L. (2009). Tingkatan Pemahaman Mahasiswa pada Konsep Fisika. Media Infotama, Vol. 4, No. 8, Hal. 14-22.

[2]Munawaroh, W. (2011). Deskripsi Pemahaman Calon Guru Fisika Terhadap Konsep-Konsep Fisika Pada Materi Pokok Gerak Lurus Di Iain Walisongo Semarang. Skripsi Fakultas Tarbiyah IAIN Walisongo malang.

[3] Muslim \& Suhandi, A. (2012). Pengembangan Perangkat Pembelajaran Fisika Sekolah Untuk Meningkatkan Pemahaman Konsep Dan Kemampuan Berargumentasi Calon Guru Fisika. Jurnal Pendidikan Fisika Indonesia, Vol. 8, Hal.174183.

[4] Guisasola, J., Almudi, J. M. \& Zubimendi, J. L. (2004). Difficulties in Learning the Introductory Magnetic Field in the First Years of University. Sciences Educations, Hal. 443-464.

[5]Scaife, T. M. \& Heckler, A. F. (2010). Student Understanding of the Direction of Magnetic Force on a Charged Particle. American Journal of Physics, Vol. 78, No. 8, Hal. 869-878.

[6]Sudjana.(1996). Metoda Statistika. Bandung: Tarsito 